\title{
Economic Institutions and Autocratic Breakdown: Monetary Constraints and Fiscal Spending in Dominant-Party Regimes*
}

\author{
Cristina Bodea (Michigan State University) \\ Ana Carolina Garriga (CIDE) \\ Masaaki Higashijima (Tohoku University)
}

Accepted 2017 Journal of Politics

\begin{abstract}
In dominant party regimes, party cadres' participation in decision-making constrains dictators from arbitrarily changing policy. Party based regimes are also better at mobilizing supporters in exchange for extensive patronage. The conventional wisdom is that these two mechanisms work together to prolong dominant party regimes. However, under certain conditions, the elite-level constraints restrict autocratic leaders' ability to engage in patronage distribution. We focus on monetary institutions, arguing that when central bank independence overlaps with the collective decision-making in dominant party regimes, dictators have diminished control over the central bank. Thus the central bank is effective enough to restrict expansionary fiscal policy, reducing the mobilization of supporters through patronage and increasing authoritarian breakdown risk. Analyses on data from 1970 to 2012 in 94 autocracies find that high central bank independence in dominant party regimes increases the likelihood of breakdown. Moreover, independent central banks in partybased autocracies contribute to lower fiscal expenditures.
\end{abstract}

* Paper delivered in the PEDD Conference (February 22-24, 2017) at the University of Munster, Germany. A former version of this paper was presented at the 2016 annual meeting of the American Political Science Association (Philadelphia, USA), Kobe University, and the Virtual Workshop of Authoritarian Regimes (VWAR). Authors are listed alphabetically. Higashijima acknowledges support from the Zengin Foundation for Studies on Economics and Finance (Tokyo, Japan). Garriga acknowledges support from the Mexican National Council for Science and Technology (CONACYT, Convocatoria 291164). 
When do authoritarian regimes collapse ${ }^{1}$ We focus on institutional constraints on spending that make it difficult for dictators to use fiscal policy as a tool to stay in power. The conventional wisdom in the recent research on authoritarian politics is that dominant party dictatorships are resilient to regime change (Geddes 1999, Magaloni 2008, Svolik 2012). Two mechanisms explain why dominant party regimes experience fewer breakdowns. First, because in dominant party regimes, decision-making is made by the dictator and other party cadres, the dictator cannot arbitrarily use policy and patronage, independent of ruling elites' preferences (Boix and Svolik 2013, Frantz and Ezrow 2011, Magaloni 2008). This, in turn, reduces the incentives of ruling elites to stage coups d'état. Second, party-based regimes also have an advantage in incorporating the preferences of the party's rank-and-file using wellorganized networks (Greene 2010, Magaloni 2006). Having grassroots political support, autocrats with institutionalized ruling parties mobilize supporters, often in exchange of distributing extensive patronage, and can "win big" in elections.

Although the literature assumes that these two mechanisms work together to prolong party-based regimes, we contend that under certain conditions the elite-level constraint (first mechanism) may make it harder for the autocrat to engage in patronage distribution (second mechanism). In this paper, we explain how central bank independence constrains the use of patronage for survival purposes. Central banks can have crucial effects on fiscal and monetary policy outcomes, as long as governments face political constraints such as checks and balances, party competition, and media transparency(Alt and Lassen 2006, Stasavage 2003)(Alt and Lassen 2006, Stasavage 2003)(Alt and Lassen 2006, Stasavage 2003)(Alt and Lassen 2006, Stasavage 2003)(Alt and Lassen 2006, Stasavage 2003). In particular, in the

\footnotetext{
${ }^{1}$ We use terms autocracy, dictatorship and authoritarianism interchangeably. "Party-based" autocracies and "dominant party" regimes are used interchangeably to refer to an autocracy where "control over policy, leadership selection, and the security apparatus is in the hands of a ruling party" (Geddes et al. 2014: 318).
} 
presence of such political constraints, it is more difficult for political leaders to infringe the autonomy of legally independent central bankers, resulting in low inflation and a healthy fiscal balance (Bodea and Hicks 2015b, Bodea and Higashijima 2015, Broz 2002, Keefer and Stasavage 2003). To a great degree, the consensus in this literature - that central bank independence matters in democracies - has emerged because it has been hard to identify the political constraints that might operate in dictatorships. ${ }^{2}$ Political constraints are weaker in authoritarian regimes, yet there is important variation across autocratic regime types. We argue that when high legal central bank independence overlaps with the collective decisionmaking in dominant party regimes, dictators are constrained from arbitrarily transgressing central bankers' preferences. Thus, central bank independence becomes effective enough to prevent the dictator from engaging in expansionary fiscal policy. Such a spending constraint, in turn, reduces dictators' ability to mobilize party supporters by using patronage, increasing the chances of authoritarian breakdown.

We test our theory using a newly collected global dataset of legal central bank independence and fiscal expenditures from 1970-2012. We first test the effect of central bank independence on autocratic breakdown. Our findings show that, in dominant party regimes, high central bank independence (CBI) increases the probability of autocratic breakdown. This probability is statistically significantly higher than that of the other autocratic regime types. That is, high levels of CBI do not affect the likelihood of autocratic breakdown in military, monarchy, or personalist regimes. This result is robust to methods controlling for country heterogeneity and instrumental variable techniques dealing with the possible endogeneity between autocratic breakdown and central bank reforms. In addition, we find support for our posited causal mechanism and show that, in party-based regimes, independent central banks

\footnotetext{
${ }^{2}$ Another challenge has been the lack of data on central bank independence for a large set of authoritarian regimes.
} 
are linked to lower fiscal expenditures, suggesting that central banks can work as an effective spending constraint in autocracies with highly institutionalized ruling parties.

The paper makes important contributions. Our findings suggest that the conventional wisdom in the authoritarian politics literature may need re-thinking: Under some conditions, dominant party regimes do not survive longer than other autocratic regimes. That is, when high legal central bank independence overlaps with the collective decision-making in dominant party regimes, dictators have a harder time controlling the central bank leading to regime instability. Also, we show that economic institutions like independent central banks can be consequential even in some autocracies, challenging the comparative political economy literature that has shown thus far that only in democracies can central banks be effective and credible, autonomous actors.

\section{Autocratic Regime Survival and the Roles of Dominant Parties}

Extant literature on authoritarian politics has pointed to multiple factors affecting autocratic survival. In particular, a key research question in the literature is whether and how institutions in autocracies contribute to the survival of autocratic regimes. One strand of research suggests that authoritarian institutions help dictators stay in power. For instance, autocratic elections allow autocrats to gather information on the distribution of regime support or demonstrate invincibility by scoring overwhelming election victories (Magaloni 2006, Reuter and Robertson 2012, Simpser 2013). Authoritarian legislatures provide autocrats with a venue to co-opt ruling elites (Blaydes 2011, Boix and Svolik 2013), make credible policy concession towards the opposition (Gandhi 2008, Gandhi and Przeworski 2007), or divide and rule opposition forces (Lust-Okar 2004). On the other hand, other research suggests that political institutions may destabilize autocracies under certain conditions. For instance, Lindberg (2006) argues that repetitive elections in multi-party 
contexts contribute to further democratization in Africa. Similarly, Roessler and Howard (2009) and Brownlee (2009) argue that competitive authoritarian regimes are more likely to democratize than both hegemonic and closed authoritarian regimes.

In the institutions literature, one of the strongest predictors of authoritarian survival is whether autocrats base their rule on the presence of dominant parties (e.g., Huntington 1968, Huntington and Moore 1970). Recently, Geddes (1999) has asserted that dominant party regimes or party-based regimes are more resilient to autocratic breakdown, compared to military and personalist regimes (see also Magaloni 2008, Magaloni and Kricheli 2010). Military regimes are the most likely to collapse because military juntas are often willing to agree with democratization and get back to the barracks as long as the status of the military is guaranteed after transitions. In personalist regimes, on the other hand, dictators cannot rely on credible political institutions to co-opt ruling elites, making personalist autocracies more likely to fail than dominant party regimes. In addition to autocratic survival, subsequent research finds that dominant party regimes are also better at dealing with domestic terrorism (Wilson and Piazza 2013), civil war (Keefer 2008), coup d'état (Cox 2008, Geddes 2008), and economic stagnation (Gandhi 2008, Gehlbach and Keefer 2011). ${ }^{3}$

Dominant parties in autocracies have two main functions. First, they enable autocratic leaders to make a credible power-sharing deal with other ruling elites (Boix and Svolik 2013, Magaloni 2008, Svolik 2012). Dictatorships have a serious commitment problem: The dictator is uncertain about members of the ruling coalition remaining loyal and foregoing a coup d'etat, whereas ruling elites weigh the risk of purge by the dictator. Dominant party organizations convey that the dictator will not arbitrarily eliminate political elites and thus effectively respond to ruling elites' concerns. By institutionalizing party organizations,

\footnotetext{
${ }^{3}$ In contrast, Wright and Escriba-Folch (2012) claim that authoritarian parties are associated with a higher likelihood of democratization because those parties help autocratic elites protect their political interests after democratic transitions.
} 
dictatorships create a functioning collective-decision making body through which governing elites reduce the risk of dictators abusing power or monopolizing policy and leadership selection (Geddes, et al. 2014). For example, Gehlbach and Keefer (2012:622) argue that "collectively-organized supporters are better able to impose a variety of checks on leaders and to impose sanctions for predatory behavior that would not otherwise be possible". Franz and Ezrow (2011) also find that, in party-based regimes where the elite coalition acts as a collective veto player, policy stability tends to be high. The institutionalization of a dominant party also allows the autocrat to develop patterned career promotions among ruling elites, thereby mitigating ruling elites' fear of political uncertainty (Magaloni 2008).

The second role of dominant parties is a mobilization function based on rent distribution or the provision of local public goods. By incorporating a large number of citizens as party members, autocrats can build broad support. The mobilization of mass support under dominant party regimes relies heavily on the distribution of patronage, with examples stretching from Mexico, to Malaysia and Egypt (Blaydes 2011, Greene 2010, Magaloni and Kricheli 2010:128-130, Pepinsky 2007). In many dominant party regimes, "the party controls land titles, fertilizers, subsidized housing, scholarships, food, construction materials, and many other privileges, which are distributed to the most loyal members of the party” (Magaloni and Kricheli 2010:128). Moreover, dominant party’ dense, large networks enable the dictator to effectively monitor party members' voting behavior, thereby increasing the marginal effect of patronage distribution on regime support. Mobilizing a large number of supporters and controlling rents through party networks, the dictator projects regime strength, deterring regime insiders from staging coup d'état (Geddes 2008). In contrast, autocrats in the other types of authoritarian regimes (monarchy, military, and personalist regimes) depend much less on mobilization of mass support and rents distribution via party networks. 
The literature suggests that the above-mentioned two functions - the power-sharing and mobilization roles - work together to explain the longevity of party-based regimes. Yet, empirically, even within the category of dominant party regimes, there is a significant variation in authoritarian survival. Using Geddes et al.'s (2014) dataset of autocratic regime types, we find that, although on average party-based regimes last longer (28.44 years, versus 11.64 years for non-party-based regimes), there is remarkable variance in the duration of party-based regimes: Among the 43 party-based regimes that experienced breakdown from 1970 to 2010, Mexico's PRI rule was the longest (84 years), whereas there are quite a lot of party-based regimes that collapsed sooner than the average of non-party-based regimes like Honduras (1972, 8 years), Nicaragua (1990, 10 years), Serbia (2000, 8 years), Rwanda (1973, 10 years), Bangladesh (1975, 3 years), and Cambodia (1979, 3 years).

We note the variation in party-based regime survival and explore the conditions under which the two key roles played by dominant parties are at odds with each other. Specifically, we explore the conditions when the elite-level power-sharing makes it harder for dictators to spend to buy-off regime supporters via party networks. To do this, we shed light on the role of economic institutions in autocracies. In particular, we focus on central banks, which have been largely ignored by the literature on autocratic politics, despite its institutional turn.

\section{Central banks in authoritarian regimes}

A large literature discusses the determinants and consequences of reforms granting the central bank independence from the political process (Alesina and Summers 1993, Bodea and Hicks 2015a, b, Broz 2002, Cukierman, et al. 1992, Garriga 2016, Grilli, et al. 1991, Keefer and Stasavage 2003, Maxfield 1997, McNamara 2003, Polillo and Guillén 2005). Most research links the effectiveness of central bank independence - regarding price stability, foreign direct investment, fiscal policy, or better conditions in credit markets - to the 
presence of democratic institutions. These findings might suggest that autocracies do not have reasons to grant independence to their central banks.

With notable exceptions (Boylan (1998), Maxfield (1997), Johnson (2016)), the role of central bank independence in autocracies has been underexplored. However, it is not rare for authoritarian regimes to reform the independence granted to their central banks. Between 1970 and 2010, there were 130 reforms in regimes coded as authoritarian by Geddes, Wright and Frantz (2014). Of those reforms, 102 increased and 28 decreased the legal independence of the central bank. Figure 1 (a) shows the yearly average number of central bank reforms in autocracies, and the average level of legal central bank independence among autocracies. ${ }^{4}$ The average central bank independence in autocracies is 0.45 , which is very close to the average of democratic observations in the same period (0.48). The frequency and direction of reforms differ depending on the type of authoritarian regime (Figure 1 (b)). Dominant party regimes and personalist dictatorships reform their central banks more often than other types of authoritarian regimes - more than $4.7 \%$ of the observations in these groups register a reform affecting central bank independence. Regarding the average levels of legal central bank independence, personalist dictatorships have the highest level of independence, followed by monarchies, dominant party regimes, and military regimes.

[Figure 1 about here]

Of note, central banks reforms are not clustered at particular times in the tenure of autocracies. Although there are more reforms in the earlier years of authoritarian regimes than later in their tenure, the distribution of reforms throughout the autocratic rule is relatively uniform (Appendix Figure A1 (a)). Also, the percentage of observations experiencing central bank reforms is not especially high in the years before regime

\footnotetext{
${ }^{4}$ Central bank independence is from Garriga (2016) and is coded as the Cukierman et al. (1992) index, ranging from 0 (lowest) to 1 (highest) levels of CBI.
} 
breakdown. In the whole sample, $3.6 \%$ of observations experience a reform in any year prior to regime breakdown, and we observe a similar figure $(3.8 \%)$ in the five years prior to regime breakdown (Appendix Figure A1 (b)). Finally, we do not observe an increasing number of reforms immediately prior to regime breakdowns - which will ease some of our endogeneity concerns. Of the 130 central bank reforms in autocracies, four occurred the year before the authoritarian breakdown - none in dominant party dictatorships - and five happened two years before the regime change (Appendix Figure A1(c)).

In much of the literature, independent central banks are an institutional rule that shields monetary decision-makers from political pressures to increase inflation, given that inflation can help produce short-term boosts in economic growth and employment (Barro 1986, Barro and Gordon 1983, Kydland and Prescott 1977). Delegation to independent central banks gives priority to the goal of inflation-rate stability over other political goals (Rogoff 1985). However, research in political science has questioned the universal validity of this principle: CBI should have the intended effects in environments where institutions are not changed whimsically, and where some (other) institutional mechanisms guarantee the respect of central bank law. Democracies are characterized by procedures that integrate more actors with veto power (Bernhard 1998, Hallerberg 2002, Keefer and Stasavage 2003). This makes rules stable and more likely to have a de facto bite. Furthermore, the democratic political process is more transparent, making rule violations evident to the public and the opposition (Broz 2002, Stasavage 2003). Finally, broad rule of law guarantees certain levels of compliance with laws giving autonomy to bureaucratic agencies like the central bank (Bodea and Higashijima 2015). Although price stability - the key focus of modern central banks - may be better achieved in democracies, independent central banks also perform other functions, and may have different effects across institutional settings. 
To understand the effects of independent central banks in authoritarian regimes, it is necessary to recognize that central banks may be granted independence to pursue other goals, beyond inflation control. For example, authoritarian leaders may use CBI to lock-in liberal policies or tie the hands of future rulers (Boylan 1998, 2001). Broz (1998) sees early central banks as commitment mechanisms to honor the repayment of debt, that increased states' capacity to finance military spending. Others argue that the autonomy of the central bank results from the accumulation of decisions made by different rulers in past critical junctures (Bell and Feng 2014, Taylor 2009). ${ }^{5}$ Yet another string of research points to the informational value of removing the central bank from political control (Bernhard 1998, Crowe 2008). ${ }^{6}$

Why would autocracies choose to delegate monetary policy and agree to legislation that nominally gives more autonomy to the central bank? If we assume that the overwhelming concern of autocrats is to maintain power, then a nominally independent central bank can play two important roles. As we explain below, it can create the appearance of competence on economic issues (domestically and internationally), and it can deflect the blame for economic hardship when the economy deteriorates.

\section{Central bank independence: Competence on economic issues and blame deflection}

In opposition to the delegation and informational mechanisms above, countries may be uncertain about the benefits of CBI. Thus, the trend in CBI reform coincides with the publication of studies showing a correlation between CBI and low inflation in developed countries. It also coincides with the International Monetary Fund's decision to make lending conditional on central bank reform (International Monetary Fund 2013, McNamara 2002,

\footnotetext{
5 In line with the literature on "endogenous institutional development" (Capoccia 2016).

${ }^{6}$ Bernhard (1998) argues that the key job of a central bank - monetary policy - is highly technical and can have unexpected consequences and uneven effects. Because of this, and because they lack the expertise, coalition partners and back-bench legislators prefer policy information and a monetary policy that is carried out by an independent central bank.
} 
Polillo and Guillén 2005). An important literature argues therefore that, as trade and investment became global, legal central bank independence was a signal of good economic governance, and a way to attract foreign investors.

Maxfield (1997) prominently suggests that in the developing world, CBI reform signals creditworthiness to potential investors. Using case studies from mostly authoritarian countries, she shows that central bank autonomy is more likely when countries have low capital account restrictions or balance of payment problems. McNamara (2002) argues that central bank reforms come from a "logic of organisational mimicry and global norms of neoliberal governance" (p. 48) and not the efficiency, functionalist logic underlined by the delegation literature. Similarly, Polillo and Guillen (2005) argue that competition among states leads to the adoption of institutions prevalent in each country's environment and show that, in the 1990s, the trend in CBI reform was driven by exposure to foreign direct investment and multilateral lending. Bodea and Hicks (2015a) combine the logic of competition for capital with the functionalist logic in the delegation literature, and find that central bank reform is driven both by competition and learning about when central bank can be credible, as well as by imitation of social peers from networks of inter-governmental organizations. Johnson (2016) argues that there is a global norm of central bank independence and that transnational actors - major central banks, the IMF, the European Union - contributed to central bank law reforms in post-communist countries. The same transnational actors, she argues, contributed to the subsequent transformation of national central bank staffers and de facto law implementation.

In addition, independent central bankers also offer autocrats an opportunity to deflect the blame for economic hardship. Compared to their democratic counterparts, autocratic leaders are exposed to a high risk of forcible removal from office (Chiozza and Goemans 2011), and, "as solitary leaders", dictators could be held fully responsibility for policy 
failures (Tomz 2009, Weeks 2012). However, even in authoritarian regimes, delegation can mitigate blame attribution (Krause 2000). The central banker can become a scapegoat for poor economic performance - in countries from Georgia (The Moscow Times 2015) to Liberia (Yates 2017). Ultimately, the central banker can be replaced, as in Algeria, as a result of the negative consequences the oil price drop on the economy (Reuters News Service 2016). In another example, in January 2017, Venezuela's president Maduro fired the head of the Central Bank, who was blamed for the unrest that followed the execution of a presidential order - the release of bigger denomination banknotes (Martinez and Ulmer 2017).

If autocracies grant independence to their central banks to signal competence or to defuse blame, this independence may be binding under certain conditions. We argue that this should hold especially for dominant party regimes: The participation of the party cadres in the decision-making process - the "elite-level constraint" - can work as veto point constraints, making it possible for the central bank to be a de facto power player in economic policy. In such cases, relatively autonomous central bankers, acting in compliance with the original intent of the autocrat, may prevent the dictator from engaging in expansionary fiscal policy. This should undermine the second mechanism that is habitually argued to contribute to the duration of party-based regimes and have important consequences for its survival.

\section{Central banks and fiscal policy}

Legal central bank independence is important for fiscal spending because independence places restrictions on government borrowing from the central bank. ${ }^{7}$ In most cases, delegation of monetary policy entails a fiscal component as well: Central bank legislation can prohibit the bank from providing the government with advances or securitized lending

\footnotetext{
${ }^{7}$ The fiscal component of central bank independence is important for developing countries, with weak domestic financial markets and difficulties accessing foreign capital Fry (1998).
} 
(Cukierman, et al. 1992). The law can also stipulate that if lending from the central bank is permitted, the more conservative central bank decides on the terms.

Autocrats may be putting into law the global norm favoring independent central banks because they copy the institutions that proved to work for the macro-economy of democracies, or to deflect responsibility for poor economic outcomes. However, central bank governors and their staff, when taking office, are trained and socialized into the global norm of central banking, including the key issues of inflation control and independence from politics (Adolph 2013, Johnson 2016, McNamara 2002). In developing countries, fiscal policy and whether the central bank finances the government are intimately linked to inflation control. For example, Sikken and de Haan (1998) show for a sample of 30 developing countries that fiscal deficits result in higher rates of money growth. ${ }^{8}$ Also, Neyapti (2003) shows that for 54 developed and developing countries budget deficits contribute to inflation, particularly when the central bank is not independent. Thus, central bankers in autocracies, if given autonomy, should have a clear preference for controlled spending.

\section{Why dominant party regimes should be more vulnerable to fiscal policy limits}

As discussed above, dictatorships with a dominant party are especially resilient to regime change (Geddes 1999). The two reasons that make them resilient, however, may also make them vulnerable to monetary constraints. Autocratic veto players can help give de facto teeth to legally independent central banks who can then act as a break on patronage spending, a key contributor to the longevity of party-based dictatorships.

First, in dominant party regimes, other party cadres need to agree with the dictator to make decisions, at least when compared to predatory personalist regimes. This elite-level constraint, in return for dissuading elites from staging coups, may work as checks or veto

\footnotetext{
${ }^{8}$ A large literature links fiscal deficits in rich countries to higher inflation and inflation expectations (e.g., Ardagna, et al. 2007).
} 
points that protect the central bank's preference for controlled spending (Frantz and Ezrow 2011:10-11). In addition to playing the role of political constraints, the dominant party may also help disseminate information on the dictator's behavior to party cadres. This, in turn, allows the ruling elites the possibility of collective action when dictators misbehave (Gehlbach and Keefer 2011, 2012). Due to the availability of information in dominant party regimes, autocrats may find it more difficult to transgress the stipulated autonomy of central bankers. These elite-level constraints pale in comparison with the ones found in democracies. Yet, it is plausible that under dominant party regimes, the dictator - who prefers to spend resources to satisfy a broad array of party supporters - may not be able to fully go against central bankers' preferences. Consequently, central bank independence becomes effective enough to prevent the dictator from engaging in expansionary fiscal policy.

Second, dominant party regimes rely heavily on patronage to mobilize party supporters. Therefore, if central banks restrain fiscal spending in autocracies, this is most likely to influence party-based regimes. Under party-based regimes, using extensive party networks, the autocrat is able to garner a large number of votes. However, this is possible as long as the autocrat can buy loyalty via various ways of patronage distribution. For instance, Greene (2010) argues that dominant party regimes' success in winning consecutive elections and surviving, depends primarily on their ability to politicize public resources for partisan purposes. The opposite should be holding then, as well: Dominant party rule is threatened if the dictator's access to public resources is limited. The autocrat's necessity to engage in extensive spending in dominant party regimes makes these regimes especially vulnerable to fiscal constraints. With limits on resources, dominant party dictators may find it difficult to mobilize supporters and stay in power, paving a way for authoritarian breakdown. ${ }^{9}$

\footnotetext{
${ }^{9}$ Clark et al. (2013) show that constraints on fiscal policy - together with monetary constraints - are associated with shorter tenure in democratic governments.
} 
The experience of some autocratic leaders with an independent central bank supports the plausibility of our argument. If legal delegation was toothless, autocrats should have had no reason to actually adjust the law governing the relationship between the central bank and the government. For example, over the years, there have been two reforms to the Egyptian Central Bank directed against a powerful central bank, in order to return to the government more tools to control the macroeconomy. Although the public justification of these reforms was the central bank's empowerment (Iyer 2011), they have overall restricted autonomy. For instance, although the 1975 reform was more explicit regarding limits to lending to the government, it also eliminated the prohibition for the central bank's governor to hold other public offices. Following an open disagreement between the Egyptian Central Bank's Governor and the minister of Finance, in which the Central Bank received most of the ministry's attributions (El-Din 2001), a reform in 2003 subordinated the goal of price stability to the general economic policy of the State, and dictated that the goals of monetary policy needed to be determined in agreement with the government. The new statute shortens the tenure of the central bank's governor, who reports directly to the president. The reform also enacted vaguer limits to the government's ability to use the central bank's credit, restricting the bank's financial independence. "Fiscal and monetary policy authority, therefore, is highly centralized in the executive branch with the president and his cabal of experts essentially free to act without restriction" (Blaydes 2011:79). In fact, under the weakened autonomy of the central bank, the Egyptian government resorted to a variety of methods to distribute patronage toward political supporters, such as infrastructure developments, pension raises, bonuses payment for government employees, and vote-buying.

Our argument is that central bank independence influences autocratic breakdown in autocratic regimes with both elite-level constraints and dependence on patronage distribution (i.e., dominant party regimes). It is important thus to note that, although royal families in 
monarchies (Herb 1999) and military juntas in some military regimes (Barros 2001) may work as elite-level constraints, those regimes' survival does not hinge on support garnered by the distribution of local public goods. Therefore, the fiscal limits that the combination of CBI and elite constraints generate do not affect the survival of monarchic and military regimes. Similarly, personalist regimes rely heavily on patronage to sustain political support, but personal dictators are not constrained by other ruling elites. In such situations, legal CBI need not be binding, and thus should not influence the likelihood of regime breakdown.

The empirical implication from our discussion is that an autonomous central bank influences the ruler's ability to retain power in dominant party regimes. Our hypothesis is therefore that: Central bank independence increases the likelihood of regime collapse in dominant party regimes. Second, we will test the causal mechanism that: Central bank independence restricts fiscal spending in dominant party regimes.

\section{Empirical analysis}

Dependent variable Regime breakdown is well defined in the literature and captures "fundamental changes in the formal and informal rules that identify the group from which leaders can be chosen and determine who can influence policy (the leadership group)" (Wright, et al. 2015:288). Using Geddes et al.'s (2014) data on autocratic regimes that captures regime failure in autocracies, we focus on regime breakdown, which codes whether a given autocratic regime collapses in a given year. A value of 1 shows that a country-year experiences a regime breakdown. Although on average party-based regimes are more likely to survive than other types of autocracies, there is variation in their duration (Figure 2(a)).

[Figure 2 around here]

Independent variables $\quad$ Our purpose is to estimate the effect of central bank independence on the likelihood of dominant party regimes experiencing a regime change. To 
distinguish among autocracies, we use Geddes et al.'s (2014) categorization of autocratic regime types. This dataset identifies four types of autocratic rule - party-based, military, personalist, and monarchic regimes. The categorization depends on "whether control over policy, leadership selection, and the security apparatus is in the hands of a ruling party (partybased dictatorships), a royal family (monarchies), the military (rule by the military institution), or a narrower group centered around an individual dictator (personalist dictatorship)" (Geddes, et al. 2014:318). The regime type variables are dichotomous. If a country is a party-based regime, then it is coded as 1 and zero otherwise. ${ }^{10}$

We measure central bank independence (CBI) using Garriga's (2016) dataset of legal CBI, which covers democracies and autocracies from 1970-2012. CBI is measured as an index that codes countries' laws governing the central bank. The index ranges from 0 (lowest independence) to 1 (highest independence), and combines 16 dimensions related to four components of independence (Cukierman, et al. 1992), on a country-year basis. These criteria include: CEO's characteristics (appointment, dismissal, and term of office of the chief executive officer of the bank); policy formulation attributions (who formulates and has the final decision in monetary policy, and the role of the central bank in the budget process); central bank's objectives; and central bank's limitations on lending to the public sector.

To test our hypothesis, we interact the party-based regimes dummy with the CBI index. We expect a negative coefficient for the party-based regime - as the literature finds, but a positive coefficient for the interaction term with CBI, showing that party-based regimes turn more unstable at higher levels of $C B I$.

Based on the previous literature (Escribà-Folch, et al. 2015, Geddes, et al. 2014) we include additional control variables in our models: logged GDP per capita, GDP growth, trade openness (imports plus exports relative to GDP), logged population (all from World

${ }^{10}$ Appendix G shows disaggregated autocracy types and tests their conditional effects. 
Development Indicators, WDI), oil-gas value per capita (Ross 2012), ${ }^{11}$ and the average level of democracy for a country's neighbors. All control variables are lagged one year.

\section{Estimation method}

Autocratic breakdown takes the values of 0 or 1 . Therefore, we first run pooled probit models. Following Wright, et al. (2015), we focus on the autocracies sample (countries that are autocratic at time t-1) to examine if they experience regime changes in year t. We also use year and regional dummies to control for time and region-specific unobservable confounding factors, as well as cubic splines and country clustered robust standard errors.

Country-fixed effects are frequently used to control for unit-level heterogeneity. This is not ideal for our data, however. One of our main independent variables - party-based regimes - varies little over time, and the dependent variable is dichotomous. Thus, countryfixed effects models drop countries that do not experience any time-series changes in the dependent variable and authoritarian regimes types, raising the issue of selection bias. Instead, we also use a model that condition the effect of the explanatory variables on their respective country means, as a substitute for country fixed effects (Wooldridge 2002). This means that the model includes all independent variables and their country averages. ${ }^{12}$

An important concern for inference is the existence of endogeneity between central bank reform and democratization. We can imagine that autocratic countries, which are likely to breakdown, may also start economic reforms including central bank independence (Boylan 1998. Of note, Maxfield (1997) argues the contrary: Central banks in Brazil, Thailand, Mexico and South Korea were granted more autonomy when the government's tenure was secure. Also, Appendix Figure A2(b) indicates a uniform distribution of central bank reform over regime duration, rather than a cluster around regime breakdown. However, if fragile

\footnotetext{
${ }^{11}$ The total oil-gas production multiplied by the current price and divided by total population.

${ }^{12}$ Escriba-Folch and Wright (2015) use the same technique and the same dependent variable.
} 
regimes are prone to reforming their central bank laws, then estimation results may be biased. We deal with potential reverse causality by using deeper lags of the central bank independence variable, as well as instrumental variable techniques.

\section{Empirical results}

Figure 2 (b) shows kernel density plots for the duration of party-based regimes at different levels of CBI. Dominant party regimes with low CBI survive longer than those with high independence. Consistent with our story, the mean survival for party-based regimes with low $\mathrm{CBI}$ is 38 years, whereas a dominant party regime with high $\mathrm{CBI}$, average 24 years.

Table 1 presents our main results. Model 1 does not include the interactive term of the party-based regime dummy with the CBI variable. The CBI variable does not have a statistically significant effect on regime breakdown, suggesting that legal central bank is toothless in autocratic regimes that lack elite-level constraints. Party-based regimes are negatively correlated with autocratic breakdown, consistent with the conventional wisdom.

[Table 1 and Figure 3 about here]

Models 2 (probit) and 3 (probit with unit means) interact autocratic regime types with the $\mathrm{CBI}$ variable. In both models, the interaction term is positive and statistically significant at the $5 \%$ and $1 \%$ levels, respectively. These results suggest that the negative impact of partybased regimes on the risk of autocratic breakdown becomes weaker and may even turn into positive when $\mathrm{CBI}$ is high. ${ }^{13}$ We use Model 2 to predict probabilities of regime breakdown at different levels of CBI for dominant party regimes. Figure 3 shows the predicted probability of party-based regime breakdown. When CBI is low (0.1) the predicted probability of party-

\footnotetext{
${ }^{13} \mathrm{CBI}$ does not condition regime breakdown for other types of autocracies (Appendix G).
} 
based regime breakdown is $0.4 \% .{ }^{14}$ When CBI is high $(0.8)$, the predicted probability increases to $6 \% .^{15}$

In order to deal with potential endogeneity, we run three additional models: First, we use a deeper lag of the central bank independence variable (Model 4). Model 1 includes a one-year lagged CBI, and here we lag the variable five additional years. ${ }^{16}$ Second, we use instrumental variables (IV) probit regression (Model 5). As discussed, a government's decision to start central bank reforms is often influenced by the spread of the international norm in favor of independent central banks. In fact, the level of CBI in geographically close countries is positively correlated with the country's degree of CBI. Yet, neighbors' CBI plausibly does not directly affect the prospect of regime breakdown, thus satisfying the exclusionary restriction condition. ${ }^{17}$ We use the neighboring countries' yearly average of CBI, which is positively and statistically significantly correlated with the level of CBI in a given country (correlation 0.52). We use Stata's ivprobit command to instrument for CBI and its interactions. ${ }^{18}$ Finally, we use linear regression instrumental variable techniques (Stata

${ }^{14}$ Cases that illustrate this situation are Poland and Yugoslavia in the 1970s and 1980s, Taiwan in the 1980s and 1990, Vietnam since 1997, or Singapore until 1998.

${ }^{15}$ Examples of dominant party regimes with these levels of CBI include Senegal, Ivory Coast and Niger (members of the Central Bank of West African States), or Indonesia in 1999. ${ }^{16}$ Lagging CBI up to ten years gives very similar results.

${ }^{17}$ In order to exclude the possibility that neighbors' central bank reforms first induce their democratization, which then leads to the country's autocratic breakdown, we control for neighbors' mean score of Polity IV. We test whether the exogeneity assumption holds by including the instruments as controls in the first model and we find that the instruments are not statistically significantly associated with autocratic breakdown. This analysis strongly suggests that our instruments are exogenous from the dependent variable (See Appendix B2). ${ }^{18}$ We use four instruments for the $C B I$ and $C B I^{*}$ Dominant Party variables: The one and six year lags of Neighbors' Average CBI and Neighbors' Average CBI* Dominant Party. The 
ivreg2), because the estimation provides better instrumental variable diagnostic tests than ivprobit models (Model 6), including tests for exogeneity (Hansen J) and weak instruments tests (Kleibergen-Paap rk Wald F). IV probit's Wald statistic is a test of exogeneity, ${ }^{19}$ yet the model does not provide additional statistics for the weakness of these instruments.

Models 4-6 produce results that are similar to our baseline model. In Models 4 and 5, the interaction term is positive and statistically significant, again indicating that, when $\mathrm{CBI}$ is high, autocracies are more likely to collapse under party-based regimes. In Model 5, the Wald test of exogeneity indicates that we cannot reject the null hypothesis of exogeneity, indicating support for the pooled probit model estimates (Model 2). In the linear estimation (Model 6), the interaction term $C B I^{*}$ Party-Based is jointly statistically significant at the $0.5 \%$ level and a graphical representation of the probability of regime breakdown shows that high CBI remains correlated with autocratic breakdown in dominant party regimes (Appendix C). These results strongly suggest that our conclusion is not sensitive to a possibility of reverse causality between $\mathrm{CBI}$ and regime change.

Not every autocratic breakdown leads to democracy. Between 1970 and 2010, only 52 percent of regime breakdowns result in democratic transitions. Theoretically, we do not have distinct expectations for different types of regime transitions, and splitting the sample into democratic versus autocratic transitions worsens the problem of rare events. Still, to examine whether different regime transitions make a difference for our hypothesis, we use two additional variables. One is democratic transitions, coded as a 1 if a country democratizes after an autocratic breakdown, and otherwise 0 (Geddes, et al. 2014). In contrast, we measure autocratic transitions as the other type of regime breakdown, coded as a 1 if a dictatorship choice for the lagging structure is based on the ivreg model's Hansen $\mathrm{J}$ test for exogeneity of parameters. For the results of the first stage models, see Appendix B1.

${ }^{19}$ It tests the significance of the correlation coefficient between the errors of the first and second stage equations. 
collapse and is followed by another autocracy, and 0 otherwise. Appendix Figure D1 (a, b) shows our results for democratic transitions and transitions to other autocratic regimes. ${ }^{20}$ The pattern is similar for both kinds of transitions: At higher levels of CBI, dominant party regimes have a higher predicted probability of experiencing democratic and autocratic transitions. These results suggest that central bank reforms under party-based regimes do not always lead to democratic reforms. The presence of independent central banks, thus, is not able to predict the likely outcome of a regime breakdown.

\section{Additional robustness checks}

We conduct a battery of sensitivity analyses to make sure our results are robust to (1) alternative measurements of democracy and dictatorship, (2) other estimation strategies, (3) identifying possible outliers (country and region), and (4) additional controls. Instead of Geddes et al. (2014), we use three alternative, widely-used measures of democracy and dictatorship (Boix et al. (2013), Cheibub et al. (2010) and Polity IV from Marshall and Jaggers $(2012)^{21}$ ). These measures do not alter our results (Appendix E-1).

We also use other estimation strategies to deal with possible methodological problems. The likelihood of autocratic breakdown may change depending on the country's geographical location - due to proximity to western countries, and close attention by the international society (Levitsky and Way 2010). This may make measurement errors correlate within regions, which possibly induces an underestimation of standard errors. We use robust standard errors clustered by region and our estimations do not change (Appendix E-2). In order to explore between-country variations while considering unit heterogeneity, we use random-effects probit model and this model do not influence the results (Appendix E-2). To

\footnotetext{
${ }^{20}$ Detailed results are available in Appendix D.

${ }^{21}$ A country is a democracy if the Polity IV score is greater than 6.
} 
consider time dependence, we employ cubic time polynominals (Carter and Signorino 2010) instead of splines, with unchanged results(Appendix E-2).

We also conduct Jackknife analyses to consider possible outliers. We exclude each country (region) one by one to investigate whether our results are sensitive to a particular country or region. We find that our main results are not influenced by exceptional cases. ${ }^{22}$ Finally, we include additional controls that may affect both central bank independence and autocratic breakdown such as economic growth, electoral authoritarian regimes, and colonial origins (former British, French, and Spanish colony dummies). These additional control variables do not affect our main results (Appendix E-3).

\section{Causal mechanism: Limits on fiscal spending}

We expect that central bank independence in party-based autocracies encourages autocratic breakdown because independent central bankers place limits on dictators' patronage spending. Therefore, we test whether CBI is negatively associated with fiscal spending in dominant-party regimes. The dependent variable is the annual fiscal expenditure as a share of the GDP. ${ }^{23}$ For these models we use linear regressions with country-fixed effects to control for unit-level heterogeneity, as well as year-fixed effects. We also include the lagged dependent variable to mitigate serial correlation, and to account for the path dependence of fiscal decisions. We report country-clustered robust standard errors.

The key explanatory variables are the same as in the analysis of breakdown: the CBI index (Garriga 2016), party-based regime dummy (Geddes et al. 2014) and their interaction. We also include the following controls (Bodea and Higashijima 2015): election years, logged GDP per capita (WDI), GDP growth (WDI), oil-gas value per capita (Ross 2012), capital

\footnotetext{
22 The results are available upon request.

${ }^{23}$ Data is from Bodea and Higashijima (2015), supplemented with IMF Article IV and Annual Country Reports. (http://www.imf.org/external/np/sec/aiv/index.aspx; date accessed: January 2017).
} 
openness (the Chinn-Ito Financial Openness Index, Chinn and Ito 2008), trade openness (WDI), population size over 65 (WDI), and fixed exchange rate regimes (Reinhart and Rogoff 2004). We also introduce two other autocratic regime types (personalist and monarchy), the democracy dummy (Geddes et al. 2014), and their interactions with the CBI index while setting the spend-thrifty military regimes as the reference category. ${ }^{24}$ Excluding democratic countries from the sample yields the similar results (Appendix F Model 1). Except the election year dummy variable, all other variables are lagged one year.

[Table 2 about here]

Table 2 presents the results. Model 7 does not interact the CBI and party-based regimes variables. $\mathrm{CBI}$ is not statistically significant, suggesting that legal central bank independence does not impact the fiscal outcomes across all political regimes. Model 8 examines our hypothesis and interacts the $\mathrm{CBI}$ index and the party-based regime dummy. The interaction term $C B I^{*}$ Party-Based is negative and statistically significant. Figure $4(a, b)$ illustrates the conditional effects. Figure 4(a) looks at the difference in the marginal effect of central bank independence for military and party-based regimes. In party-based regimes, higher CBI leads to lower spending, whereas in military regimes, the effect of $\mathrm{CBI}$ is indistinguishable from zero. Figure 4(b) shows the marginal effect of party-based regimes on expenditure across different levels of CBI. When CBI is low, party-based regimes tend to spend more, which is consistent with the conventional wisdom that dominant party regimes rely on patronage distribution to maintain power. This includes a handful of party-based regimes famous for spending and extensive patronage distribution via party networks like Mugabe's Zimbabwe, China, KMT's Taiwan, Suharto’s Indonesia, Singapore, and Vietnam.

${ }^{24}$ In our data, military regimes' mean of fiscal expenditure is $19.17 \%$ of GDP, whereas the other types of autocratic regimes spend more on average (party-based regimes: $26.49 \%$; monarchy regimes: $31.19 \%$, personalist regimes: $21.85 \%$ ). Setting any other autocratic regime type as the reference category gives us a similar pattern (Appendix F, Models 2-3). 
Yet, as the central bank becomes more independent, party-based regimes refrain from spending, and when the CBI index is greater than 0.75 , the marginal effect turns negative. ${ }^{25}$

\section{Conclusion}

This paper explores the conditions behind autocracies breakdown, focusing on whether monetary institutions influence autocracies' fiscal policy. We argue that independent central banks constrain fiscal spending and thus encourage regime change, but only in dominant party dictatorships. In these regimes, elite-level constraints restrict dictators' ability to transgress central bankers' preferences and fully manipulate fiscal policy for their survival. Cross-national statistical analyses find that legal central bank independence in party-based autocracies is positively correlated with the likelihood of regime breakdown. Additional tests also suggest that high CBI in dominant party regimes limits fiscal spending.

Our paper contributes to understanding the conditions under which party-based regimes have long tenures. We find that party-based regimes are resilient to autocratic breakdown under some conditions. Yet our research suggests that the two contributing factors to party based regime durability - the presence of the collective decision-making and its reliance on broad-based patronage distribution - may be at odds with each other when the central bank has been granted legal independence. These findings suggest that further research is needed to disentangle the different functions of well-institutionalized ruling parties in dictatorships.

Our results also speak to the broader literature on the effect of institutions in authoritarian regimes. The recent literature on autocratic political institutions emphasizes that formal institutions are not mere "window dressing." Contrastingly, researchers have settled on the idea that central bank reforms cannot be expected to matter in autocracies because

${ }^{25}$ Party-based autocracies with high CBI include Belarus, Senegal, Niger, or Ivory Coast. 
dictators are not constrained, and can easily change laws. Our research shows, however, that legal central bank independence may tie autocrats' hands when dominant party cadres work in collective decision-making as political constraints. In so doing, we point to the conditions under which a formal economic institution - an independent central bank - can influence fiscal policy in dictatorships, where central bankers have long been considered paper tigers.

\section{References}

Adolph, Christopher A. (2013) Bankers, Bureaucrats, and Central Bank Politics: The Myth of Neutrality, Cambridge Studies in Comparative Politics. Cambridge, MA: Cambridge University Press.

Alesina, Alberto, and Lawrence H. Summers. (1993) Central Bank Independence and Macroeconomic Performance: Some Comparative Evidence. Journal of Money, Credit, and Banking 25: 151-63.

Alt, James E., and David Dreyer Lassen. (2006) Transparency, Political Polarization, and Political Budget Cycles in OECD Countries. American Journal of Political Science 50: 530-50.

Ardagna, Silvia, Francesco Caselli, and Timothy Lane. (2007) Fiscal Discipline and the Cost of Public Debt Service: Some Estimates for OECD Countries. The B.E. Journal of Macroeconomics 7.

Barro, Robert J. (1986) Recent Developments in the Theory of Rules versus Discretion. Economic Journal 96: 23-37.

Barro, Robert J., and David Gordon. (1983) Rules, Discretion and Reputation in a Model of Monetary Policy. Journal of Political Economy 91: 101-21.

Barros, Robert. (2001) Personalization and Institutional Constraints: Pinochet, the Military Junta, and the 1980 Constitution. Latin American Politics and Society 43: 5-28.

Bell, Stephen, and Hui Feng. (2014) How Proximate and 'Meta-Institutional' Contexts Shape Institutional Change: Explaining the Rise of the People's Bank of China. Political Studies 62: 197-215.

Bernhard, William. (1998) A Political Explanation of Variations in Central Bank Independence. American Political Science Review 92: 311-27.

Blaydes, Lisa. (2011) Elections and Distributive Politics in Mubarak's Egypt. New York, NY: Cambridge University Press.

Bodea, Cristina, and Raymond Hicks. (2015a) International Finance and Central Bank Independence: Institutional Diffusion and the Flow and Cost of Capital. Journal of Politics 77: 268-84.

. (2015b) Price Stability and Central Bank Independence: Discipline, Credibility, and Democratic Institutions. International Organization 69: 35-61. 
Bodea, Cristina, and Masaaki Higashijima. (2015) Central Bank Independence and Fiscal Policy: Can the Central Bank Restrain Deficit Spending? British Journal of Political Science FirstView: 1-24.

Boix, Carles, Michael Miller, and Sebastian Rosato. (2013) A Complete Data Set of Political Regimes, 1800-2007. Comparative Political Studies 46: 1523-54.

Boix, Carles, and Milan W. Svolik. (2013) The Foundations of Limited Authoritarian Government: Institutions, Commitment, and Power-Sharing in Dictatorships. The Journal of Politics 75: 300-16.

Boylan, Delia M. (1998) Preemptive Strike: Central Bank Reform in Chile's Transition from Authoritarian Rule. Comparative Politics 30: 443-62.

_ . (2001) Defusing Democracy. Ann Arbor, MI: University of Michigan Press.

Brownlee, Jason. (2009) Portents of Pluralism: How Hybrid Regimes Affect Democratic Transitions. American Journal of Political Science 53: 515-32.

Broz, J. Lawrence. (1998) The Origins of Central Banking: Solutions to the Free-Rider Problem. International Organization 52: 231-68 . (2002) Political System Transparency and Monetary Commitment Regimes. International Organization 56: 861-87.

Capoccia, Giovanni. (2016) When Do Institutions "Bite"? Historical Institutionalism and the Politics of Institutional Change. Comparative Political Studies 49: 1095-127.

Carter, David B., and Curtis S. Signorino. (2010) Back to the Future: Modeling Time Dependence in Binary Data. Political Analysis 18: 271-92.

Cheibub, José Antonio, Jennifer Gandhi, and James Raymond Vreeland. (2010) Democracy and Dictatorship Revisited. Public Choice 143: 67-101.

Chinn, Menzie, and Hiro Ito. (2008) A New Measure of Financial Openness. Journal of Comparative Policy Analysis 10: 309-22.

Chiozza, Giacomo, and Hein Erich Goemans. (2011) Leaders and International Conflict. New York, NY: Cambridge University Press.

Clark, William Roberts, Sona N. Golder, and Paul Poast. (2013) Monetary Institutions and the Political Survival of Democratic Leaders. International Studies Quarterly 57: 556-67.

Cox, Gary W. 2008. "Authoritarian Elections and Leadership Succession, 1975-2000." In Working Paper: University of California, San Diego.

Crowe, Christopher. (2008) Goal Independent Central Banks: Why Politicians Decide To Delegate. European Journal of Political Economy 24: 748-62.

Cukierman, Alex, Steven B. Webb, and Bilin Neyapti. (1992) Measuring the Independence of Central Banks and Its Effect on Policy Outcome. The World Bank Economic Review 6: 353-98.

El-Din, Gamal Essam. 2001. "Independence for Central Bank: President Mubarak has dismantled the Economy Ministry and given control of monetary policy to the Central Bank." Al-Ahram Weekly, (November 2001). 15-21.

Escribà-Folch, Abel, Covadonga Meseguer, and Joseph Wright. (2015) Remittances and Democratization. International Studies Quarterly 59: 571-86. 
Frantz, Erica, and Natasha M. Ezrow. (2011) The Politics of Dictatorship: Institutions and Outcomes in Authoritarian Regimes: Lynne Rienner Publishers.

Fry, Maxwell J. (1998) Assessing Central Bank Independence in Developing Countries: Do actions Speak Louder than Words? Oxford Economic Papers 50: 512-29.

Gandhi, Jennifer. (2008) Political Institutions under Dictatorship. New York, NY: Cambridge University Press.

Gandhi, Jennifer, and Adam Przeworski. (2007) Authoritarian Institutions and the Survival of Autocrats. Comparative Political Studies 40: 1279-301.

Garriga, Ana Carolina. (2016) Central Bank Independence in the World: A New Data Set. International Interactions 42: 849-68.

Geddes, Barbara. (1999) What Do We Know About Democratization After Twenty Years? Annual Review of Political Science 2: 115-44.

_ 2008. "Party Creation as an Autocratic Survival Strategy." Working paper.

Geddes, Barbara, Joseph Wright, and Erica Frantz. (2014) Autocratic Breakdown and Regime Transitions: A New Data Set. Perspectives on Politics 12: 313-31.

Gehlbach, Scott, and Philip Keefer. (2011) Investment without Democracy: Ruling-Party Institutionalization and Credible Commitment in Autocracies. Journal of Comparative Economics 39: 123-39.

. (2012) Private Investment and the Institutionalization of Collective Action in Autocracies: Ruling Parties and Legislatures. The Journal of Politics 74: 621-35.

Greene, Kenneth F. (2010) The Political Economy of Authoritarian Single-Party Dominance. Comparative Political Studies 43: 807-34.

Grilli, Vittorio, Donato Masciandaro, and Guido Tabellini. (1991) Political and Monetary Institutions and Public Financial Policies in the Industrial Countries. Economic Policy: 341-92.

Hallerberg, Mark. (2002) Veto Players and the Choice of Monetary Institutions. International Organization 56: 775-802.

Herb, Michael. (1999) All in the Family: Absolutism, Revolution, and Democracy in Middle Eastern Monarchies. Albany, NY: SUNY Press.

Huntington, Samuel. (1968) Political Order in Changing Societies New Heaven: Yale University Press.

Huntington, Samuel, and Clement Moore. (1970) Authoritarian Politics in Modern Society: The Dynamics of Established One-Party Systems: Basic Books.

International Monetary Fund. 2013. "World Economic Outlook. Transitions and Tensions." Washington, D.C. http://www.imf.org/external/pubs/ft/weo/2013/02/.

Iyer, Deepa. 2011. "Building the Capacity to Regulate: Central Bank Reform in Egypt, 2003-2009." Princeton, NJ

https://successfulsocieties.princeton.edu/sites/successfulsocieties/files/Policy_Note_I D156.pdf.

Johnson, Juliet. (2016) Priests of prosperity. Ithaca, NY: Cornell University Press.

Keefer, Philip. (2008) Insurgency and Credible Commitment in Autocracies and Democracies. World Bank Economic Review 22: 33-61. 
Keefer, Philip, and David Stasavage. (2003) The Limits of Delegation: Veto Players, Central Bank Independence, and the Credibility of Monetary Policy. The American Political Science Review 97: 407-23.

Krause, George A. 2000. "A Positive Theory of Bureaucratic Discretion as Agency Choice."

Kydland, Finn E., and Edward C. Prescott. (1977) Rules Rather Than Discretion: The Inconsistency for Optimal Plans. Journal of Political Economy 85: 473-91.

Levitsky, Steven, and Lucan Way. (2010) Competitive Authoritarianism : Hybrid Regimes after the Cold War. New York, NY: Cambridge University Press.

Lindberg, Staffan I. (2006) Democracy and Elections in Africa Baltimore, MD: The John Hopkins University Press.

Lust-Okar, Ellen. (2004) Structuring Conflict in the Arab World: Incumbents, Opponents, and Institutions. New York, NY: Cambridge University Press.

Magaloni, Beatriz. (2006) Voting for Autocracy: Hegemonic Party Survival and Its Demise in Mexico. Cambridge, MA: Cambridge University Press.

. (2008) Credible Power-Sharing and the Longevity of Authoritarian Rule.

Comparative Political Studies 41: 715-41.

Magaloni, Beatriz, and Ruth Kricheli. (2010) Political Order and One-Party Rule. Annual Review of Political Science 13: 123 -43.

Marshall, Monty G., and Keith Jaggers. "Polity IV Dataset." Center for International Development and Conflict Management, University of Maryland

Martinez, Ana Isabel, and Alexandra Ulmer. 2017. "Venezuela's Maduro has Asked Central Bank Head to Step Down." Reuters.

Maxfield, Sylvia. (1997) Gatekeepers of Growth: The International Political Economy of Central Banking in Developing Countries. Princeton, NJ: Princeton University Press.

McNamara, Kathleen. (2002) Rational Fictions: Central Bank Independence and the Social Logic of Delegation. West European Politics 25: 47-76.

McNamara, Kathleen R. 2003. "Rational Fictions: Central Bank Independence and the Social Logic of Delegation." In The Politics of Delegation, eds. Marc Thatcher and Alec Stone Sweet. Portland, OR: Frank Cass. 47-76.

Neyapti, Bilin. (2003) Budget Deficits and Inflation: The Roles of Central Bank Independence and Financial Market Development. Contemporary Economic Policy 21: 458-75.

Pepinsky, Thomas. (2007) Autocracy, Elections, and Fiscal Policy: Evidence from Malaysia. Studies in Comparative International Development 42: 136-63.

Polillo, Simone, and Mauro F. Guillén. (2005) Globalization Pressures and the State: The Global Spread of Central Bank Independence. American Journal of Sociology 110: 1764-802.

Reinhart, Carmen M., and Kenneth S. Rogoff. (2004) The Modern History of Exchange Rate Arrangements: A Reinterpretation. Quarterly Journal of Economics 119 1-48.

Reuter, Ora J., and Graeme B. Robertson. (2012) Subnational Appointments in Authoritarian Regimes: Evidence from Russian Gubernatorial Appointments. The Journal of Politics 74: 1023-37. 
Reuters News Service. 2016. "Algerian President Fires Central Bank Governor Following Oil Price Drop." Reuters, May 31, 2016.

Roessler, Philip G., and Marc Morjé Howard. 2009. "Post-Cold War Political Regimes: When Do Elections Matter?" In Democratization by Elections, ed. Staffan I. Lindberg. Baltimore, MD: The Johns Hopkins University Press. 101-27.

Rogoff, Kenneth S. (1985) The Optimal Degree of Commitment to an Intermediate Monetary Target. Quarterly Journal of Economics 100: 1169-89.

Ross, Michael L. (2012) The Oil Curse. Princeton, NJ: Princeton University Press.

Sikken, Bernd Jan, and Jakob de Haan. (1998) Budget Deficits, Monetization, and Central Bank Independence in Developing Countries. Oxford Economic Papers 50: 493-511.

Simpser, Alberto. (2013) Why Governments and Parties Manipulate Elections: Theory, Practice, and Implications, . New York, NY: Cambridge University Press.

Stasavage, David. (2003) Transparency, Democratic Accountability, and the Economic Consequences of Monetary Institutions. American Journal of Political Science 47: 389-402.

Svolik, Milan W. (2012) The Politics of Authoritarian Rule. Cambridge, MA: Cambridge University Press.

Taylor, Matthew M. (2009) Institutional Development through Policy-Making: A Case Study of the Brazilian Central Bank. World Politics 61: 487-515.

The Moscow Times. 2015. "Georgia's Central Bank Scapegoat for Country's Problems." The Moscow Times, August 10, 2015.

Tomz, Michael. 2009. "The Foundations of Domestic Audience Costs: Attitudes, Expectations, and Institutions." In Kitai, Seido, Gurobaru-shakai (Expectations, Institutions, and Global Society), eds. Masaru Kohno and Aiji Tanaka. Tokyo: Keiso-Shobo. 85-97.

Weeks, Jessica L. (2012) Strongmen and Straw Men: Authoritarian Regimes and the Initiation of International Conflict. American Political Science Review 106: 326-47.

Wilson, Matthew C., and James A. Piazza. (2013) Autocracies and Terrorism: Conditioning Effects of Authoritarian Regime Type on Terrorist Attacks. American Journal of Political Science 57: 941-55.

Wooldridge, Jeffrey M. (2002) Econometric Analysis of Cross Section and Panel Data. Cambridge, MA: MIT Press.

Wright, Joseph, and Abel Escribà-Folch. (2012) Authoritarian Institutions and Regime Survival: Transitions to Democracy and Subsequent Autocracy. British Journal of Political Science 42: 283-309.

Wright, Joseph, Erica Frantz, and Barbara Geddes. (2015) Oil and Autocratic Regime Survival. British Journal of Political Science 45: 287-306.

Yates, David A. 2017. "Over High Currency Exchange Rate: Markets, Petty Traders Ignite Protest." Daily observer, January 30, 2017. 


\section{Figures and Tables}

Figure 1: Central bank reforms and average level of bank independence

All autocracies (a)

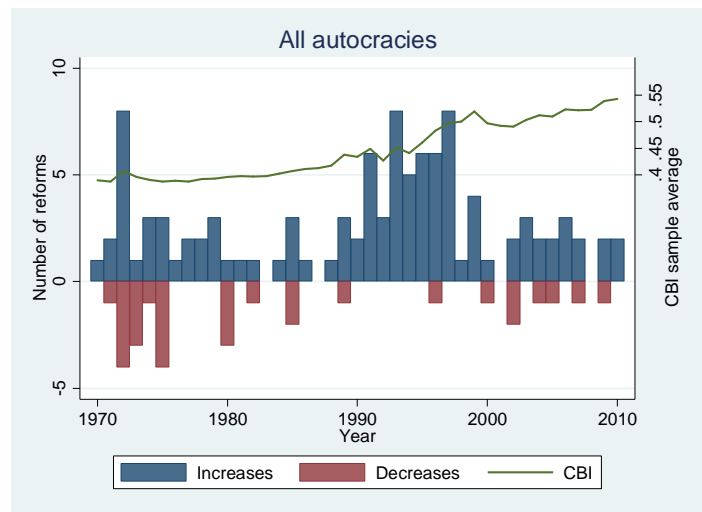

Different types of autocratic regimes (b)
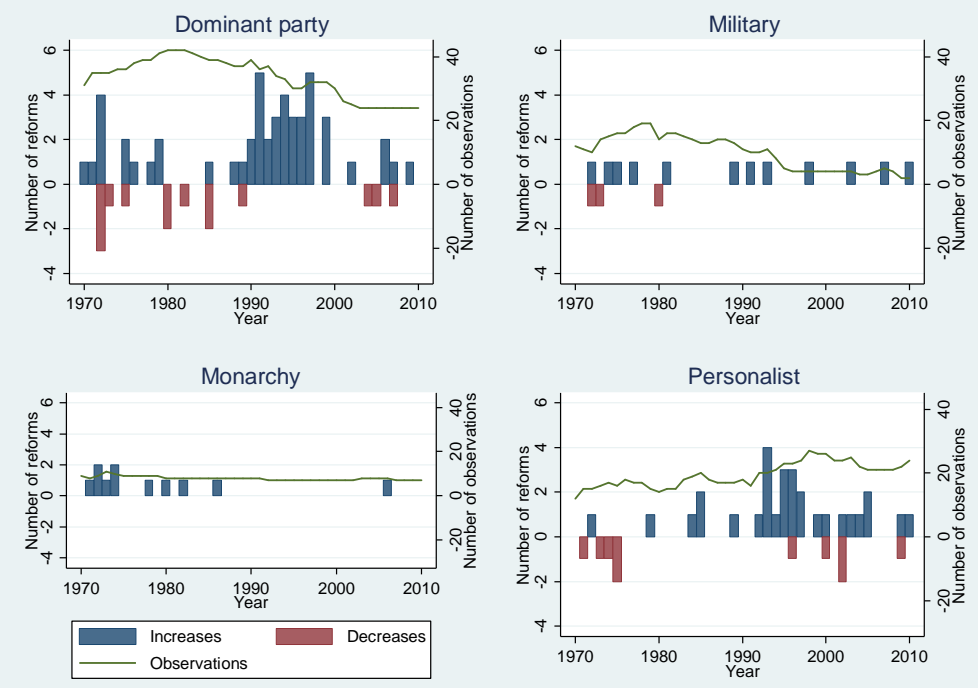


\section{Figure 2: Dominant Party Regime Duration}

Variation among Party-Based Regimes (a)

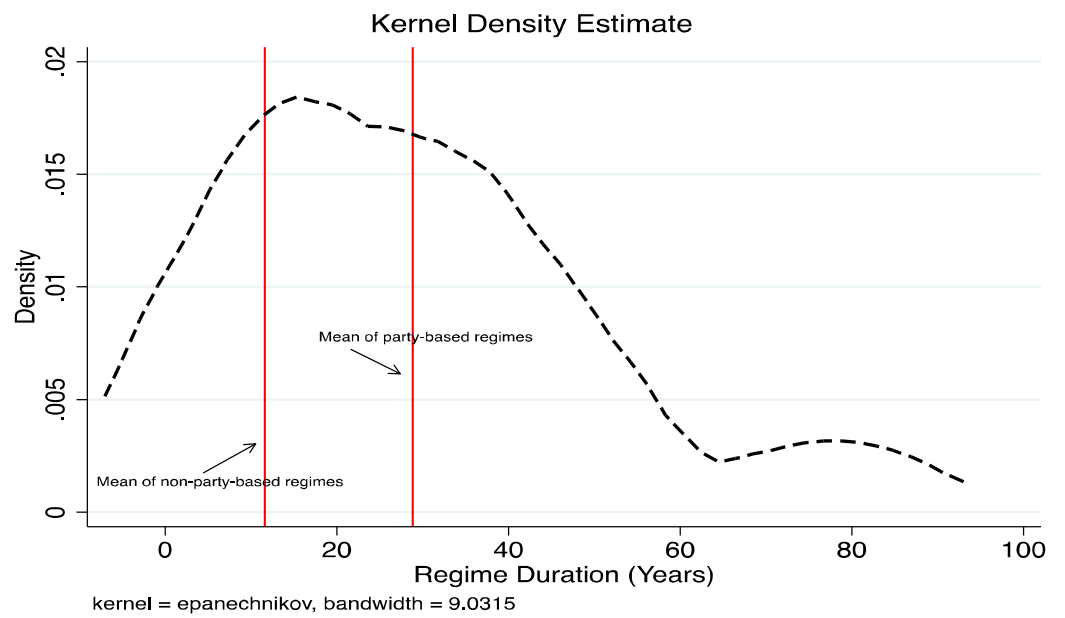

Party-Based Regimes with low/high CBI (b)

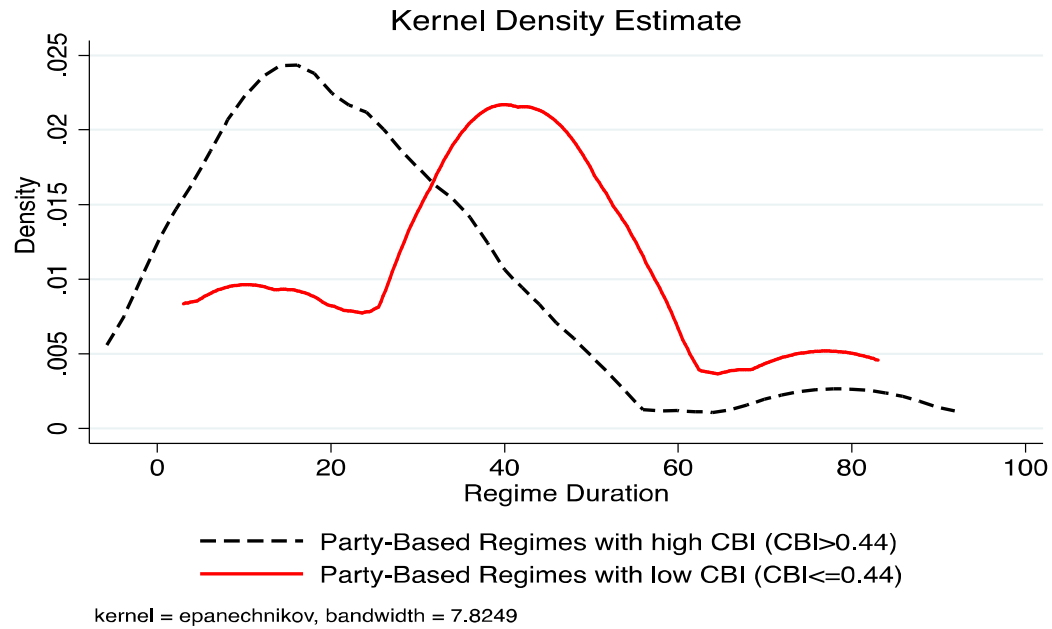

Note: The average CBI index in autocracies of 0.44 . Low $\mathrm{CBI}>0.44$; High $\mathrm{CBI}<=0.44$. 
Figure 3: Predicted probabilities for dominant party regimes

Regime Breakdown (a) (uses Model 2)

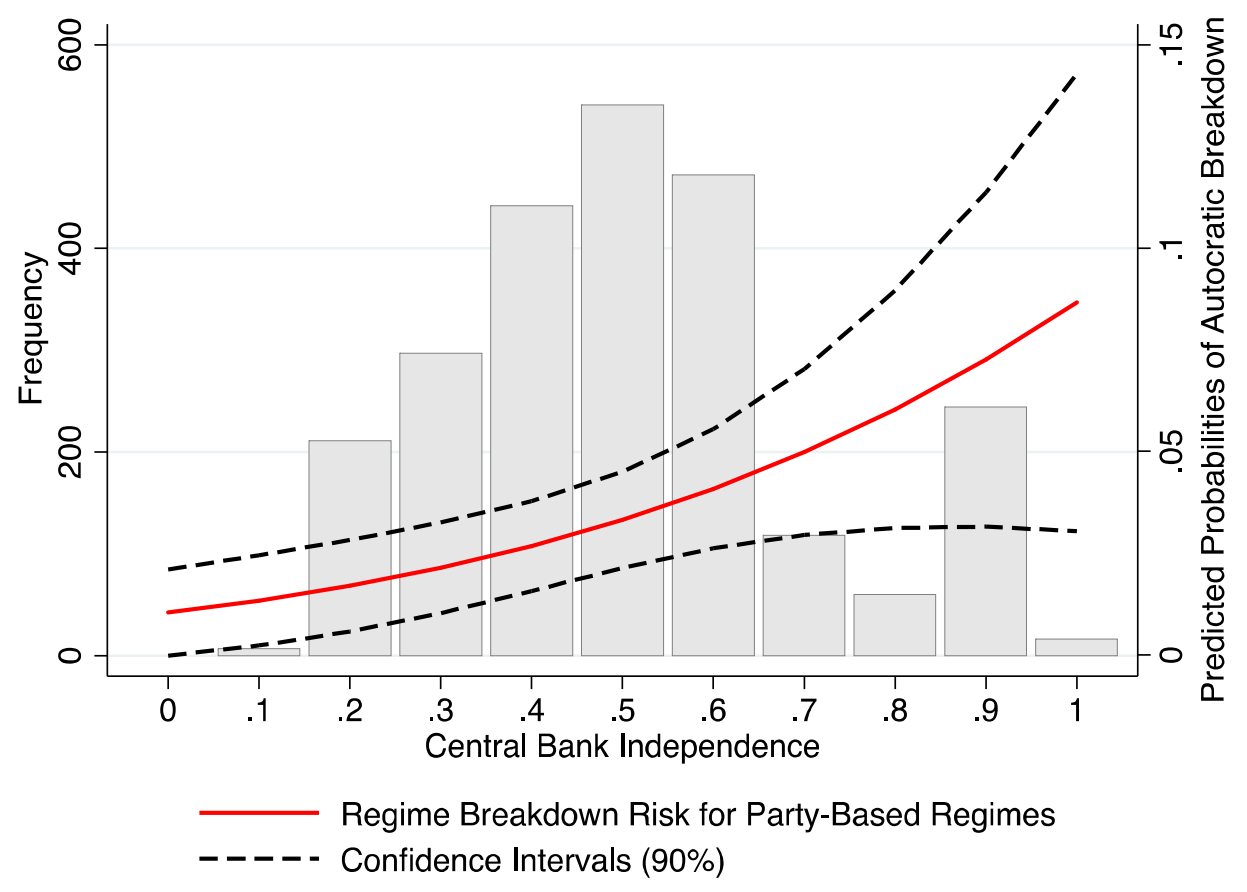




\section{Figure 4: Fiscal Expenditure}

(a) Marginal of CBI on Fiscal Expenditures

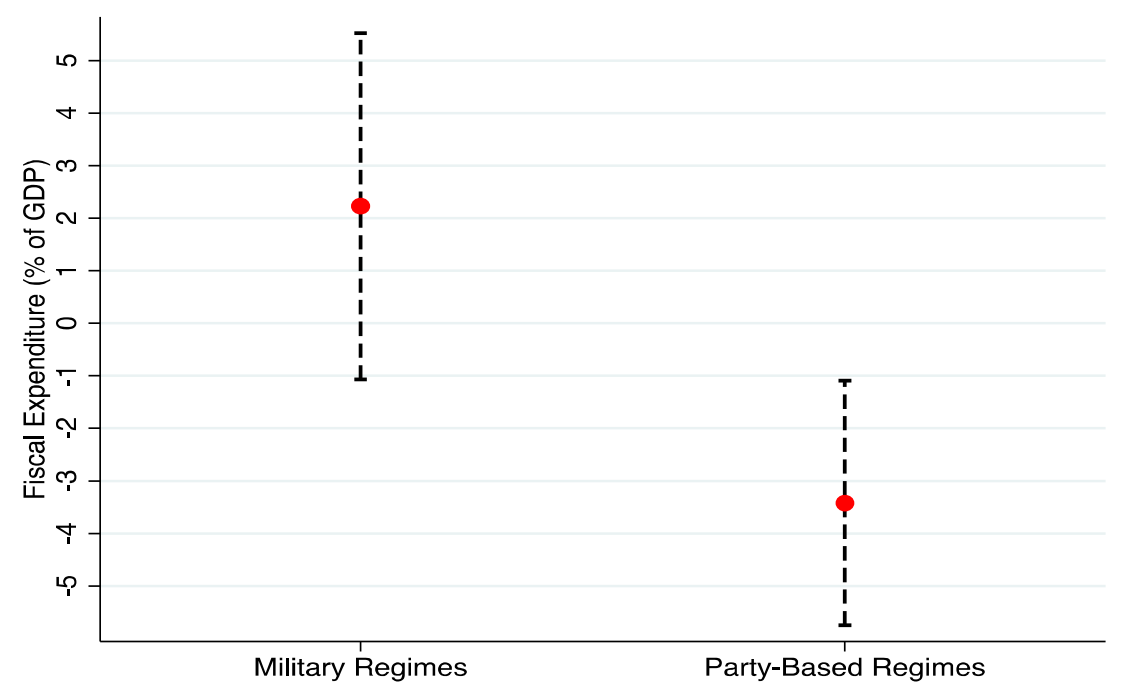

(b) Marginal of Party-Based Regimes on Fiscal Expenditures

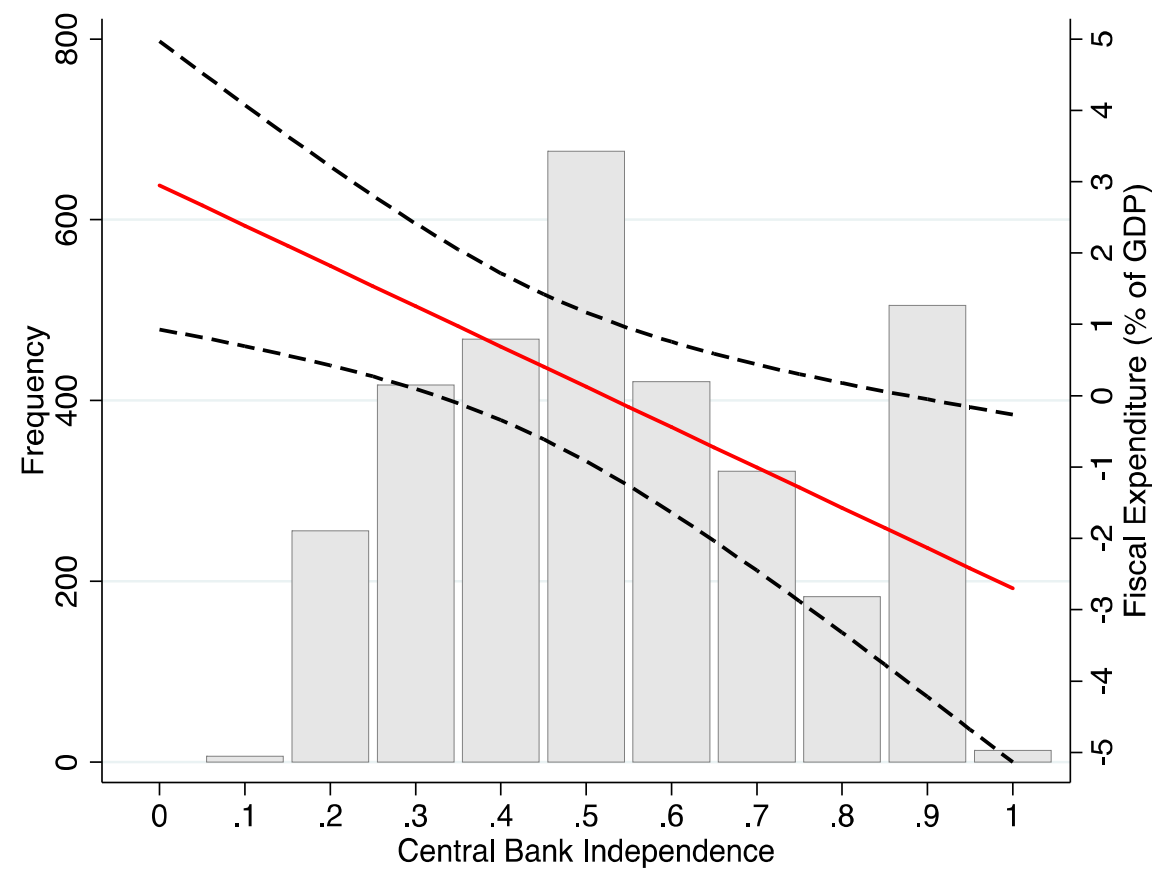

Note: Dashed lines are 90\% confidence intervals 
Table 1: Party-Based Regimes, CBI, and Regime Change in Autocracies

\begin{tabular}{|c|c|c|c|c|c|c|}
\hline & Model 1 & Model 2 & Model 3 & Model 4 & Model 5 & Model 6 \\
\hline DV & $\begin{array}{c}\text { Regime } \\
\text { Breakdown }\end{array}$ & $\begin{array}{c}\text { Regime } \\
\text { Breakdown }\end{array}$ & $\begin{array}{c}\text { Regime } \\
\text { Breakdown }\end{array}$ & $\begin{array}{c}\text { Regime } \\
\text { Breakdown }\end{array}$ & $\begin{array}{c}\text { Regime } \\
\text { Breakdown }\end{array}$ & $\begin{array}{c}\text { Regime } \\
\text { Breakdown }\end{array}$ \\
\hline Method & Probit & Probit & $\begin{array}{c}\text { Probit \& Unit } \\
\text { Means }\end{array}$ & $\begin{array}{c}6 \text { YR lagged } \\
\text { CBI }\end{array}$ & IV Probit & IV Reg \\
\hline \multirow[t]{2}{*}{ Central Bank Independence (CBI) } & 0.206 & 0.000693 & -0.903 & 0.116 & -0.935 & -0.103 \\
\hline & $(0.238)$ & $(0.274)$ & $(0.611)$ & $(0.312)$ & $(1.040)$ & (0.111) \\
\hline \multirow[t]{2}{*}{ Party-Based Autocracies } & $-0.429 * * *$ & $-0.932 * * *$ & -0.697 & $-1.071 * * *$ & $-1.585 * *$ & $-0.121 * *$ \\
\hline & $(0.133)$ & $(0.285)$ & $(0.446)$ & $(0.287)$ & $(0.617)$ & $(0.057)$ \\
\hline $\mathrm{CBI}$ *Party-Based & & $\begin{array}{l}1.036^{* *} \\
(0.517)\end{array}$ & $\begin{array}{c}2.357^{* * *} \\
(0.697)\end{array}$ & $\begin{array}{l}1.156^{* *} \\
(0.545)\end{array}$ & $\begin{array}{l}2.146^{*} \\
(1.245)\end{array}$ & $\begin{array}{c}0.162 \\
(0.113)\end{array}$ \\
\hline \multirow[t]{2}{*}{ Logged GDP per capita } & -0.0342 & -0.036 & -0.185 & -0.0193 & -0.033 & -0.010 \\
\hline & $(0.062)$ & $(0.065)$ & $(0.239)$ & $(0.083)$ & $(0.079)$ & $(0.008)$ \\
\hline \multirow[t]{2}{*}{ Logged Population } & -0.0552 & -0.0563 & -0.028 & -0.0157 & -0.055 & -0.008 \\
\hline & $(0.058)$ & $(0.059)$ & $(0.372)$ & $(0.062)$ & $(0.066)$ & $(0.005)$ \\
\hline \multirow[t]{2}{*}{ Oil-Gas Value per capita } & (0.031) & -0.031 & 0.04660 & -0.032 & -0.028 & -0.001 \\
\hline & $(0.025)$ & $(0.025)$ & $(0.077)$ & $(0.029)$ & $(0.030)$ & $(0.003)$ \\
\hline \multirow[t]{2}{*}{ Trade Openness } & -0.003 & -0.003 & $(0.001)$ & -0.002 & -0.002 & -0.0001 \\
\hline & $(0.002)$ & $(0.002)$ & $(0.004)$ & $(0.002)$ & $(0.002)$ & $(0.000)$ \\
\hline \multirow{2}{*}{ Neighbors' Democracy } & 0.020 & 0.0194 & 0.0123 & 0.013 & 0.016 & 0.000297 \\
\hline & $(0.018)$ & $(0.018)$ & $(0.025)$ & $(0.023)$ & $(0.022)$ & $(0.0021)$ \\
\hline \multirow[t]{2}{*}{ Constant } & -0.138 & -0.023 & -1.273 & -0.138 & 0.404 & $0.375 * * *$ \\
\hline & $(1.136)$ & $(1.193)$ & $(1.202)$ & $(1.136)$ & $(1.487)$ & $(0.143)$ \\
\hline Year Fixed Effects & Yes & Yes & Yes & Yes & Yes & Yes \\
\hline Region Dummies & Yes & Yes & Yes & Yes & Yes & Yes \\
\hline Time Dependence and Cubic Splines & Yes & Yes & Yes & Yes & Yes & Yes \\
\hline Wald Test of Exogeneity ( $p$ value) & & & & & 0.628 & N/A \\
\hline Kleibergen-Paap Wald F Statistic & & & & & & 42.706 \\
\hline Stock-Yogo weak ID test $5 \%$ critical values & & & & & & 11.04 \\
\hline Hansen J Statistic ( $p$ value) & & & & & & 0.376 \\
\hline Observations & 1,918 & 1,918 & 1,918 & 1,560 & 1,647 & 1,647 \\
\hline Number of Countries & 94 & 94 & 94 & 89 & 91 & 91 \\
\hline Log Pseudolikelihood & -373.76 & -372.35 & -360.14 & -297.29 & 2569.13 & \\
\hline
\end{tabular}

Note: Clustered robust standard errors in parentheses. $* * * \mathrm{p}<0.01 ; * * \mathrm{p}<0.05 ; * \mathrm{p}<0.1$. The reference category for autocratic regime type is all autocracies except party based regimes. Model 3includes variable country means for all independent variables, not shown here to conserve space. 
Table 2: Party-Based Regimes, CBI, and Fiscal Policy

\begin{tabular}{|c|c|c|}
\hline & Model 7 & Model 8 \\
\hline DV & Expenditure & Expenditure \\
\hline Sample & All Countries & All Countries \\
\hline Method & Country FE & Country FE \\
\hline \multirow[t]{2}{*}{ Lagged Dependent Variable } & $0.748^{* * *}$ & $0.745^{* * *}$ \\
\hline & $(0.028)$ & $(0.029)$ \\
\hline \multirow[t]{2}{*}{ Central Bank Independence (CBI) } & 0.439 & 2.225 \\
\hline & $(0.825)$ & $(2.004)$ \\
\hline \multirow[t]{2}{*}{ Party-Based Autocracies } & 0.462 & $2.948^{* *}$ \\
\hline & $(0.563)$ & $(1.228)$ \\
\hline \multirow[t]{2}{*}{ CBI*Party-Based } & & $-5.648^{* *}$ \\
\hline & & $(2.409)$ \\
\hline \multirow[t]{2}{*}{ Election Years } & $0.228^{*}$ & 0.219 \\
\hline & $(0.135)$ & $(0.135)$ \\
\hline \multirow[t]{2}{*}{ Democracies } & $0.821^{* * *}$ & $1.406^{* *}$ \\
\hline & $(0.305)$ & $(0.693)$ \\
\hline \multirow[t]{2}{*}{ CBI*Democracies } & & -1.716 \\
\hline & & $(1.824)$ \\
\hline \multirow[t]{2}{*}{ Personalist } & -0.0397 & $(0.319)$ \\
\hline & $(0.513)$ & $(1.061)$ \\
\hline \multirow[t]{2}{*}{ CBI*Personalist } & & 0.012 \\
\hline & & (1.999) \\
\hline \multirow[t]{2}{*}{ Monarchy } & 2.804 & $3.310^{*}$ \\
\hline & $(1.704)$ & (1.982) \\
\hline \multirow[t]{2}{*}{ CBI*Monarchy } & & -0.906 \\
\hline & & $(3.031)$ \\
\hline \multirow[t]{2}{*}{ Logged GDP per capita } & -0.139 & -0.121 \\
\hline & $(0.419)$ & $(0.429)$ \\
\hline \multirow[t]{2}{*}{ GDP Growth } & -0.00113 & -0.00427 \\
\hline & $(0.020)$ & $(0.020)$ \\
\hline \multirow[t]{2}{*}{ Oil-Gas Value per capita } & $0.000127^{*}$ & $0.000121^{*}$ \\
\hline & $(0.000)$ & $(0.000)$ \\
\hline \multirow[t]{2}{*}{ Capital Openness } & -0.094 & -0.103 \\
\hline & $(0.101)$ & $(0.100)$ \\
\hline \multirow[t]{2}{*}{ Trade Openness } & 0.00734 & 0.00816 \\
\hline & $(0.007)$ & $(0.007)$ \\
\hline \multirow[t]{2}{*}{ Population over 65} & 0.113 & 0.104 \\
\hline & $(0.106)$ & $(0.106)$ \\
\hline \multirow[t]{2}{*}{ Fixed Exchange Rate Regimes } & 0.116 & 0.0845 \\
\hline & $(0.218)$ & $(0.221)$ \\
\hline \multirow[t]{2}{*}{ Constant } & 5.198 & 4.455 \\
\hline & $(3.142)$ & $(3.150)$ \\
\hline Year Fixed Effects & Yes & Yes \\
\hline Country Fixed Effects & Yes & Yes \\
\hline Observations & 3,258 & 3,258 \\
\hline Number of Countries & 126 & 126 \\
\hline
\end{tabular}

